\title{
The Present Status of X-Ray Stress Measurement in Japan
}

by

\author{
Kazuyoshi KAMACHI
}

(Faculty of Engineering, Yamaguchi University, Yamaguchi) and Toshio SHIRAIWA

(Central Research Laboratories, Sumitomo Metal Ind., Ltd., Amagasaki)

1 緒

言

材料学会にX線応力測定部門委員会が創設されて十 年になる・初代小島公平委員長で発足したこの委員会 で，X線応力測定法の再検討と普及に力が入れられた． その当時, 测定技術標準化分科を作成してアンケート を募った．当時のアンケート集約も著者の一人が行な ったがまだ，実験室に括いて使用されているX線回折 装置の空の一つを背面反射カメラに割愛した，という 程度のところが多かった。 そして回折環の半径をだす のにグラススケールで環径を測定してそれから半径を 求めていたのである.ミクロフォトメータは高価で充 分の普及がなされていなかったし，そのころまだ理研 製の平行電極間に細い糸を張って光量を变換した電圧 をかけて，系を振らせ，その影を乾板に撮影するタイ プのフォトメータが活躍していた，その後X線の材料 強度研究に応用される範田が拡まるにつれて委員会も X線材料強度部門委員会と改称する事となった。そし て, 応力測定分科, 疲労分科, 金属材料分科, 非金属 材料分科の四分科が下部組織として置かれ分科活動が 始まった。

小島委員長は大阪大学名誉教授となられ, 京都大学 平 修二教授が二代委員長となられ, 材料強度研究へ のX線の応用が強化されるとともに，応力測定の技術， 手法执よび測定值の解釈に括ける全国統一構想が打出 され，持趌り試料による測定価のバラッキと原因調査 が始まった、材料強度方面での研究は細束X線を疲労 の研究に導入されて一つの分野が進められた。. 細束X 線技術は始め物理学的な一つの手法として用いられる

\footnotetext{
* 原稿受理 昭和46年 9 月 9 日

** 正 会員 山口大学工学部 宇部市常盤台

*** 正会員 住友金属(株)中央研究所 尼崎市西長州本通
}

かまたは fibre の研究に用いられていたのを著者等 がぜい性破壞の破面研究に応用して試行していたもの であった．細束X線法の応力測定への応用も目下研究 されつつあって微小領域の応力測定が可能になるもの と思われる。

これらの過程中各種の装置も著しい変化をとげた. 昭和四十四年に機器分科会が新たに併設され，各種の 装置の新訂などに使用者の意見を強く反映し，またメ 一カの苦哀も使用者に遡える機関として, 調査その他 を行なら事となった。

ここに扣いて従来からなされていた応力測定の統一 企画は機峨装置自身の誤差，取り扱い，扣よび構成の 上に执いても正しい測定が行なえるよう再検討される こととなった。そしてアンケートを募り装置の使用状 態の調查を行なったところ，90\%近い回答を得た。こ の調查結果を集約して報告する.

\section{2 集約 の結果}

アンケート設問については応力弾性分科白岩主査と 並川幹事の下で検討作成された。設問は 30 問あり， (1) (1)〜(11) はX線応力測定装置の普及牤よびその形式, 回折像の記録方式などに関するものであって，X線応 用測定法のポテンシャリティーを表わすものである. (2) (12) 〜 (21) は応力測定に関する 設問であって， 測定の 具体的方法に関する技術レベルを示すものである。ま た (3) (22)〜(30) は被測定物の種類形状括よび 測定の活用 に関する設問であり，今後の装置設計およびX線応力 測定法自体のあり方関する内容を示す重要なもので ある・

以上の 30問に対する回答を集約すると，まず (1) (1) 〜(11)に対して，99\%が最低一台から三台までなんらか の装置を有して扣られ，乙か子その匡とんどが応力測 
定専用機であった。この事は応力測定法ならびにその 装置がいかに普及したかを示するのであって，同時に X線応力測定法が漸く軌道にのってきた事を示吉指標 となるものである。今までの潜伏期間が長かったため, 今後本当の意味での測定と活用は急速に行なわれるよ うになると考朰てよい，その内容を具体的にかり簡潔 深まめるならば次のようである。

\section{$2 \cdot 1$ 装置に関する回答の集約}

$2 \cdot 1 \cdot 1$ 装置の普及 X線回折装置以外飞応力測 定機を少なくも一台所有して䄧られるところが多く， Cr, Co の刘陰極管をもっている. 検出は活とえぞ G. M. tube を使用しシンチレーションカウンター使用 のところる若干あった。これは検出器自体による撰択 でなく価格による撰択であると考兄られる（もっとも， シンチレーションカウンターが絶対に G. M. 計数管よ りすぐれているという明らかな理由はないが). 回折 像は汪とんどチャート自動記録方式を採用し，少数例 がプリントアウト方式で回折強度を読んで扔られた。

\section{$2 \cdot 1 \cdot 2$ 測定装置の問題点とメーカーへの要望}

測定装置に対しての問題点和よびィーカーへの要望事 項については比較的意見が狭い範囲に限られていて， 突込んだ意見は少なかった。その理由は，なおこれら 装置の利用が試験的なものであって，本格的な材料強 度，特に on line での使用は充分でないと読みとれる 節がある。最も多い問題は次のようであった。

測定機本体が大きすぎて，一寸，使用し難い面があ る. 形状複雑な場合の測定に困難を感ずる. 形状複雑 な場合は, 曲率の大きい凸面や凹面の測定に際してX 線照射部の表面の垂線が判らないので入射角の決定が 難しい, 切欠き底, 歯車の歯底などの場合は表面の垂 線は測定できてる反射X線を捉兄る事に特いて機構的 に困難がある。ことに測定機の本体が大きいとかかる 場合汉取扱いがなかなからまくいかないという事であ った。

$2 \cdot 1 \cdot 3$ 測定機の自動化と電算機直結 測定機の 自動化々電子計算機直結の方式については測定機の全 自動化は望ましいとする方向であって否定的意見は皆 無であった。しかし，今の装置の価格から考光ると恐 らく高価になるであるうと想像して，此較的低廉で設 置できるという事は全部の一致した要望であった。 100万くらいという具体的何格の希望をかかれた回答 もあった。つまり現在の装置を購入するのが手一杯で あるという感でをるっている事が読みとれる内容であ った。

データー処理に関して電子計算機直結等の自動化は, 否定的意見が強く，回折図形のチェックが絶対必要で

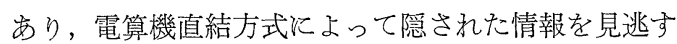
恐机がある、特に心理的には計算機の回答を信用乙易
くかつ便利であるので途中の考察や結果に対する理由 の裏付けなどが稀薄になる事があげられている。すな わち, 応力が精度上く測定されるためにはかなり良好 なプロファイルでなくてはならない.プロファイルが, 粗結晶や聚合組織のために応力測定に充分でない等の 場合には，それを選別して除くとともにと和用し て被測定対象の状態や処理過程を考光るのであるが， それらに対する考察, あるいは得られた測定值のよっ てくる理由に対する裏付けがなされなくなるといら事 を恐れているものである。この撰別までを行ならので あれば話しは別であるが前に述べた低廉な価格という

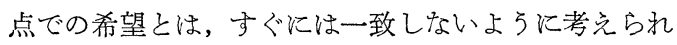
る.

$2 \cdot 1 \cdot 4$ 現場利用について 現場利用関する装 置構成がしっくりしていない点が問題になっているが， メーカ側としても, 多品種少量生産は価格高, 人手の 問題で困る事であって，この間の折合点が難しい，基 本構造の装置を作って, 適当なアタッチメント, 治具 または専用架台を作るなどによってある程度は cover できると思われるが，被測定対象が次に述べるように 千差万別である以上，これだけで解決されるとも思わ ない. 著者らの意見としてはX線管球ケース,ゴニオ， 計数器レートメータ, その他のエレメントの部分販売 をメーカが認めるならば，各自の要望に応じた装置を 各自で組上げる事などが充分満足できる方法の一つで はないかと考光る。機器分科会としては，メーカーあ るいは各測定者の要望によって被対象物とそれ適応 する装置構成のまとめ，組み合わせ飞相談する機関た り得る事もとの機能の一部之考えているので利用され たいと思うところである。

\section{$2 \cdot 2$ 測定対象について}

測定しょうとする対象物の形状は大概は次の分類に 網羅される。

\section{I．被測定物の形状}

A. 試験片

板状 $10 \mathrm{~mm} \times 50 \mathrm{~mm} \sim 60 \mathrm{~mm} \times 200 \mathrm{~mm}$, 厚さ $1 \mathrm{~mm} \sim 10 \mathrm{~mm}$ 丸棒 $10 \mathrm{~mm} \phi$, 長さ $200 \mathrm{~mm}$ くらい その他大型試験片がある。

B. 機械部分品

小形 $10 \mathrm{~mm} \phi$ 軸, リング, 軸受レース, ボル 卜等各種機械要素. 直径 0.5 1 $\mathrm{mm} \phi$ の細線。

中形 円筒 (シャフト, その他), 車軸, 霜車 (module 10 以上), 特飞歯車の歯底の 円周方向, 車輪（鉄道車輛用）, プーリ 一, 車軸のアーム, ブッシング, 工具, トーションバー, パイプ $(40 \mathrm{~mm} \phi \sim 150$ $\mathrm{mm} \phi)$, クランク軸, その他. 

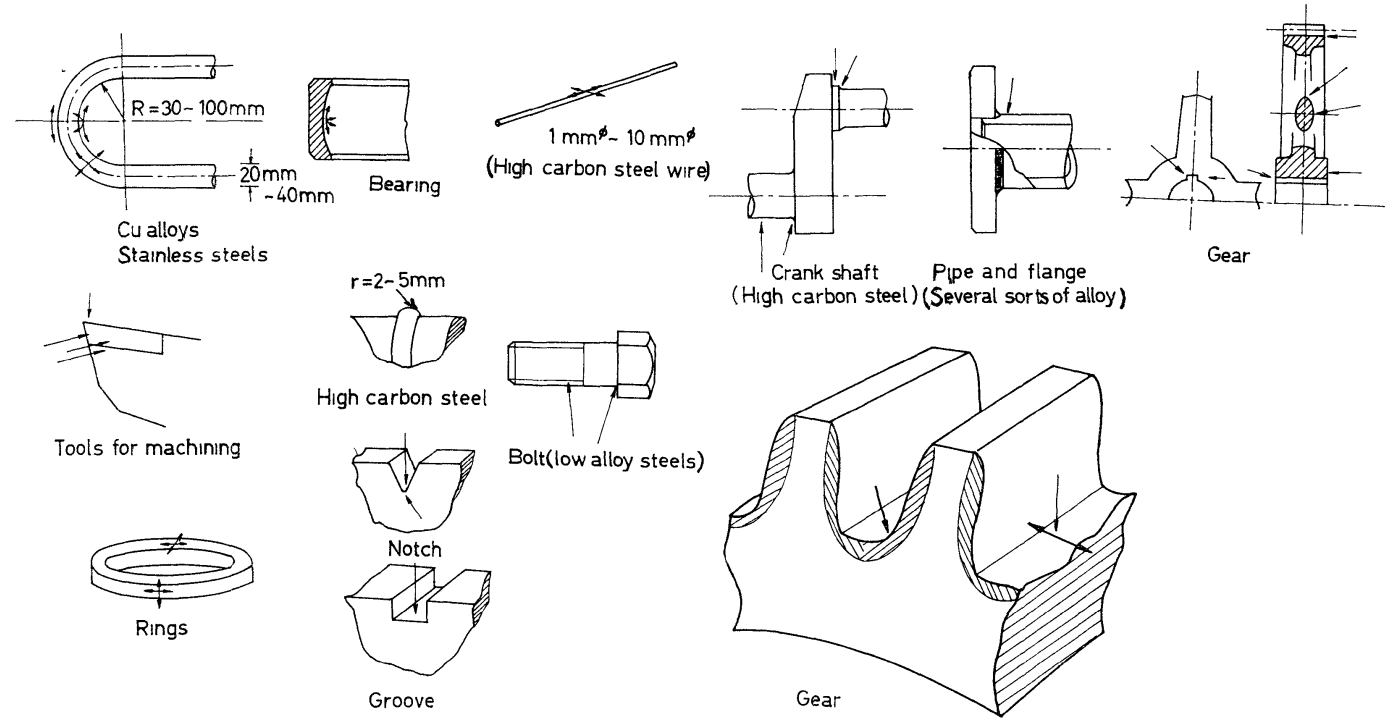

(High carbon steel) (Several sorts of alloy)

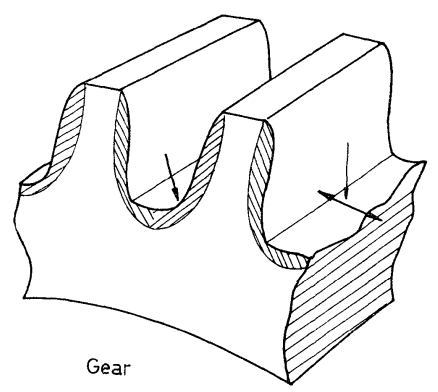

Fig. 1. Examples of difficult point for stress measurement.

大型 圧延ロール, 熱交換器, クランク軸（大 型), クランクアームの隅, 船体構造物, 压力容器, 橋梁

被測定物の測定箇所で困惑するところ

三次元曲面, 切欠き底, 隅部

曲率の大きい凸面または凹面

小形リングの内面, ボール

\section{II. 被測定材質}

材質は鉄鋼が全体の50\%を占め，高金合，合金鋼， アルミおよびアルミ合金，銅および銅合金，がそれに つぐ.その回答数の和を 100 として回答数を\%で表わ すと次のようになる。

\section{(0)鉄鋼}

○炭素鋼 $48 \%$

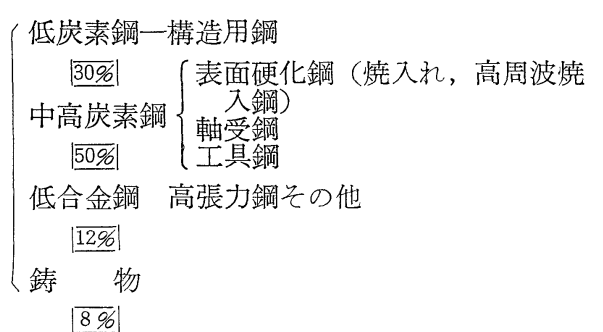

○合金鋼叔よび高合金 $38 \%$

$$
\left[\begin{array}{l}
\text { ステンレス } \overline{70 \%} \mid \\
\text { その他 }(\mathrm{Ni} \text { 合金等) }
\end{array}\right.
$$

$30 \%$

(0アルミおよびアルミ合金 7\%
(O)銅合金

(○)の他
$2 \%$

口は各種を $100 \%$ としたときの\%
$2 \cdot 3$ 応力測定に関して

応力計算は $\sin ^{2} \psi$ 法により, 測定点数は 4 点測定が ほとんどであるが 5 点ないしはそれ以上測定するとい ら回答もあった。また $0^{\circ}-45^{\circ}$ 法を採用するところも少 なからずあったが $\sin ^{2} \psi$ と比較して大きい違いのない 結果を得る場合, 測定時間短縮のため 2 点法としてい るようである.弾性係数は炭素鋼に対しては $E=21000$ $\mathrm{kg} / \mathrm{mm}^{2}$ を $100 \%$ 採用しているようであるが，ステン レス銅合金等に対する $E$ の值の回答はなく，適当な值 をやはり求めて置く必要がある。ポアソン比も例外な くレ=0.28であった．写真法を併用していられるとこ ろは案外多く，その目的は材料によっては応力測定を 写真法で行なっている活か，大略の回折線の状況を検 討するために写真をとっている，これは誠に正しい方 向であると思われる。全般的にスポッティな回折線を 写真法で，その回折環のバックグラウンドから求めら れているようである.回折線がきわめて拡散したbroadened line のときと spotty line のときの工夫につ いてはきわめて有効と思われる手法についての案は示 されていなかった．Spottyな場合，試料摇動を行な了 という回答は二，三めったが，きわめて平滑な場所に 限られた場合にのみ, 可能であると考劣られる. Broad な場合，定計数法または定時計数法を採用すればよい かと思われるが従来の応力測定装置でその方式を備光 たものが少なかったようである。

X線強度を上げることも有効であるうし，回折線の 形状を医ら物線近似（ 3 点〜 5 点）することも有効で あるが, 半価幅が $5^{\circ} \sim 6^{\circ}$ あるよ5な場合, 当然回 折線の極大部の強度は低く, 充分の計数時間を与えた ステップスキナンニングがやはり有効であるう。 
測定に関する設問で，どのょうな情報を抽出し，ど う利用するかといら事，牤よび技術上解決すべき問題， 測定值の解釈，等はほとんどがその回答を避けて和ら れる。これは研究上の秘密に属する事柄であるからと 考えている．実際そういら意味の事をかかれたところ もある。

要するに技術的には, spotty ring の場合ときわめて broad な回折環の場合の考方方と，それに対処する方 法が今後の研究課題であるとともに，いかなる場合に 応用乙て有効であるかという事と，得た結果が何を意 味するかという事が今後の研究の主題となるであろう と考觉られる。

\section{3 測定の目的}

$2 \cdot 1$ 集約した装置をもって $2 \cdot 2$ の測定対象に関す る測定を行なう目的は和およそ次のようである。

\section{$3 \cdot 1$ 品質管理および技術管理としての測定}

応力の絶対值は必要である。しかし，絶対值よりも， たとえば焼割れを起こした場合と起こさない場合の熱 処理条件と応力の測定值のデーターの堆積によって, 適当な焼入条件が見い出される。という技術管理上の 用法が大きい使用途であるように思われる。 また製造 中間工程での測定によって加圧履歴の適否の検討, 製 造特よび加工方法の検討ができるという品質管理的利 用途がこれについで大きい使用途である.かかる場合 できれば on line に执いて測定し, 測定值の精度向 上は是非必要であるがょず再現性に重点を置き，あら ゆる機会に判定法と精度の向上に努力するという考え 方である。

$3 \cdot 2$ 材料強度評価法および保守検査としての測定 機械構造物の使用中に打注る測定によって残留応力 がどう変化するかという事はきわめて重要なことであ る. 回折線の半価幅の変化と残留応力変化を系統的に
行なら事によって疲労寿命の推定, 応力腐触寿命の予 測, その他の強度評価が行なわれる。広い範团でこの 種のデーターの堆積を行なえば, 破壊事故防止が徹底 するであらうと考えられる。

\section{$3 \cdot 3$ 材料検査, 破壊原因の推定法}

残留応力の除去が充分であったかどうか，焼入れが 充分行なわれたかどうか，等の検査と方法の改善に用 いて著効があり, 強度の保証範囲の検討, 加工法の適 否等検查手段として有効である。また破壊事故原因の 推定に用いて成果を収めている.

特に金属組織学的には金属相間応力の測定, 析出, 変態等による内部応力の発生などについては, 他の切 出し法等によっては測定はできないのであって，X線 法によってのみ正しい測定ができる事をもっと重視せ ねばならない，格子面問距離の変化を，乙かも局部的 に測定する方法が金属学的に応用されないのは和かし いのであるが，従来は組織と応力が別の分野でそれぞ れ議論されていたためである。これは今後のX線応力 測定の一つの進路であることは疑いない．き裂先端部 の塑性変形と応力の問題など現今研究されつつあるが, 今後岕らゆる場合について用いられ，大きく応用分野 を広げることになるであるら。

$$
4 \text { む す び }
$$

以上「X線応力測定に関する調查」のアンケート回 答を集約した結果について述べた。設問は応力弾性分 科に㹉願いし，集約を残器分科で行なったが充分の内 容のある資料となったと思う。結果の集約はできるた け回答に忠実に行なった。今後この回答を参考にして いただいて，一層の装置の改善進歩と，研究の進展が 行なわれれば幸いである。ご協力いただいた各位に深 甚の謝意を表したい. 